\title{
The effect of midwife training in strengthening the mental health of postpartum mothers
}

\author{
Sumarni, ${ }^{1}$ Shinta Prawitasari, ${ }^{2}$ Adi Heru Sutomo, ${ }^{3}$ Ika Putri, ${ }^{1}$ Santi Yuliani ${ }^{1}$ \\ 'Department of Psychiatric, Faculty of Medicine, Public Health and Nursing, Universitas Gadjah Mada, Yogyakarta, \\ Indonesia \\ ${ }^{2}$ Department of Obstetrics and Gynecology, Faculty of Medicine, Public Health and Nursing, Universitas Gadjah Mada, \\ Yogyakarta, Indonesia \\ ${ }^{3}$ Department of Family, Community Medicine, and Bioethics, Faculty of Medicine, Public Health and Nursing, Universitas \\ Gadjah Mada, indonesia
}

\section{KEYWORDS}

Mother/infant mortality rate

Maternal blues depression

Social support Midwife training
ABSTRACT Most midwives in the Cangkringan Community Health Center and Pakem Health Center are not familiar with the symptoms of blues depression. They do not have the knowledge and skills to handle it, and social and spiritual support are not provided to postpartum women. Data showed that in the Cangkringan Community Health Center, blues depression occurs in $60 \%$ of perinatal patients; there were 2 cases due to delayed treatment, and one mother almost killed her baby. In the Pakem Health Center area, blues depression occurs in $48.1 \%$ of perinatal patients; there were 2 cases who experienced postpartum depression due to late handling, and one mother tried to commit suicide. If blues depression is not handled properly and immediately, it can cause postpartum depression, which has one of the worst complications, namely postpartum psychosis. One effort to overcome this serious social problem is by providing midwife training on early detection and handling of blues depression accompanied by social support. In this study, social support and spiritual training were done in six sessions, with meetings once a week over 1.5 months. The tools in this research included instruction with an early detection for blues depression module, social support and spiritual training for blues depression prevention, as well as the administration of the Edinburgh Postnatal Depression Scale questionnaire. Research methods in this study used presentations, discussions, role plays, practice, meetings/gatherings, and implementation. Data analysis used a quantitative descriptive approach. Research subjects consisted of 47 midwives from the Cangkringan Community Health Center and Pakem Health Center areas and 67 postpartum women from the Cangkringan Community Health Center and Pakem Health Center areas. The results showed that the average value of blues depression prevention knowledge was 43.45 before the training and afterwards, it increased to 85.20. The average value of blues depression early detection knowledge was 57.56 before the training and afterwards, it increased to 91.27. The average value of blues depression prevention skills was 36.45 before the training and afterwards, it increased to 80.25 while the average value of blues depression early detection was 51.30 before the training and afterwards, it increased to 90.20 . Blues depression in postpartum women in the Cangkringan and Pakem health centers was 57\%. Additionally, the average value of knowledge about blues depression control before the training was $43.45 \%$ which changed to $85.20 \%$ after the training with an increase of 41.75 . The average value of skills regarding prevention and early detection of blues depression before the training was 36.45 which changed to 80.85 after the training with an increase of 44.40 . The whole series of training for the midwives in the Cangkringan Community Health Center and Pakem Health Center areas could improve the knowledge and skills of midwives to overcome blues depression in postpartum women, reduce the incidence of blues depression in postpartum women, and reduce maternal and child mortality due to postpartum mental disorders.

(C) The Journal 2020. This article is distributed under a Creative Commons Attribution-ShareAlike 4.0 International license.

\section{Introduction}

One of the causes of high Maternal Mortality Rate (MMR) and Infant Mortality Rate (IMR) is the existence

*Correspondence: bu_sumarnidw@yahoo.com

Department of Psychiatric, Faculty of Medicine, Public Health and Nursing, Universitas Gadjah Mada, J. Farmako, Sekip Utara, Yogyakarta 55281, Indonesia of mothers' mental health problems. Maternal blues depression is the beginning of the occurrence of mental disorders in postpartum mothers which later can adversely affect the mother and baby. ${ }^{3}$ If blues depression is not handled properly and immediately, it can cause postpartum depression, which in turn will cause one of the worst complications, namely 
postpartum psychosis. Severe psychiatric disorders after childbirth can increase the risk of suicide by up to 70 times compared to other causes, especially in the first year after delivery. More than $50 \%$ of perinatal patients experience blues depression, which is the most common mood disorder in the postpartum period. Blues depression affects about $50-80 \%$ of postpartum women which usually appears on the first day and increases for three to five days. ${ }^{1}$

Cangkringan Health Center is $13.5 \mathrm{~km}$ from the summit of Mount Merapi while Pakem Health Center is $14 \mathrm{~km}$ from the summit of Mount Merapi. After the 2010 eruption of Mount Merapi in Cangkringan District, Sleman Regency, $60 \%$ of postpartum women experienced blues depression. ${ }^{2}$ In Jetis District, Bantul Regency, after the earthquake, $52 \%$ of postpartum women experienced blues depression. ${ }^{2}$ The eruption of Mount Merapi, which caused many casualties, tremendous damage, loss of residences, loss of work and having to move to a new place of residence, became a major stressor that further exacerbated the concerns of mothers in the perinatal period. Psychiatric disorders after disasters can be prolonged, and some will even become post-traumatic disorders for a period of more than 30 years. ${ }^{3}$ Socio-economic changes due to disasters affect the harmony of husband and wife. The husbands often have to work more to provide social support to their wives when they are pregnant and after giving birth, so that the wife has increased risk of experiencing blues depression due to isolation. ${ }^{1}$

For teenagers after the eruption of Mount Merapi, there were mainly the influences of the Lava Tour environment, workplaces on the Gendol River, and peer behavior. These risks increase the number of early marriages and extramarital pregnancies which add to the potential for blues depression. In the Cangkringan maternity clinic among perinatal patients, $60 \%$ of cases had blues depression, and there were two cases of blues depression which were due to delays in treatment that became postpartum psychosis with attempts to kill the baby. ${ }^{1}$ In Puskesmas Pakem, pregnancy rates outside of marriage are quite high. ${ }^{4}$ In 2015, cases of early pregnancy amounted to 20 cases at risk of becoming blues depression, 2 cases of late handling of cases of blues depression, and one case of a mother committing suicide. ${ }^{5}$ It was found that $48.1 \%$ of postpartum women had blues depression. ${ }^{5}$ Childbirth care costs covered by the new Universal Health Plan (BPJS) applies only to treatment for the first 24 hours and has a negative impact on the physical, psychological and social conditions of most mothers who are actually not ready to independently care for their babies. Additionally, the inability to care for themselves at home and for their child after delivery are severe stressors and triggers the emergence of blues depression.

Accordingly, this study aimed to see the effect of specialized training given to midwives in strengthening the mental health in postpartum mothers.

\section{Method}

This study used data taken from activities conducted between June to October 2018, in the Cangkringan Health Center and Pakem Health Center, Sleman, Yogyakarta. The study subjects consisted of 47 midwives and 67 postpartum mothers. The tools included a blues depression early detection module, social and spiritual support for blues depression management, the Edinburgh Postnatal Depression Scale (EPDS) questionnaire, the skills and knowledge of blues depression early detection questionnaire, and the social and spiritual support questionnaire. The methods used were lectures, discussions, role playing, practice, mentoring, and implementation. Data analysis combined both qualitative and quantitative approaches.

\section{Result}

\subsection{Characteristics of Subjects}

Midwife training was conducted in the Cangkringan Puskesmas and Pakem Puskesmas. The Cangkringan Puskesmas area covers Cangkringan Puskesmas, PKU Muhammadiyah Cangkringan, and the Azizah Midwife Clinic. The Pakem Puskesmas area includes the Puskesmas Pakem, PKU Muhammadiyah Pakem, the Felisiana Clinic, and the Fitri Nurul Clinic with as many as 47 total people.

The number of midwives who participated in the training from the Cangkringan Community Health Center which included the Cangkringan Health Center, Muhammadiyah Cangkringan PKU, and the 
Table 1. Distribution of midwifery in Cangkringan and Pakem Health Centre

\begin{tabular}{lll}
\hline Characteristics & $\mathbf{N}$ & $\%$ \\
\hline $\begin{array}{l}\text { Work office } \\
\quad \text { Cangkringan Health Centre }\end{array}$ & 23 & 52.00 \\
$\quad$ Pakem Health Centre & 24 & 48.00 \\
Age (years) & & \\
$20-29$ & 25 & 53.10 \\
$30-39$ & 12 & 25.50 \\
$40-49$ & 8 & 17.20 \\
$\geq 50$ & 2 & 4.20 \\
Education level & & \\
$\quad$ Diploma 3 & 24 & 51.00 \\
Diploma 4 & 22 & 46.00 \\
$\quad$ Bachelor Degree & 1 & 3.00 \\
\hline Total & 47 & 100 \\
\hline
\end{tabular}

Table 2. Characteristic of postpartum mothers in Cangkringan and Pakem Health Centre

\begin{tabular}{lll}
\hline Characteristics & $\mathbf{N}$ & $\%$ \\
\hline $\begin{array}{l}\text { Age (years) } \\
\quad<20\end{array}$ & 3 & 4.47 \\
$21-35$ & 50 & 74.64 \\
$\quad>35$ & 14 & 20.89 \\
Education level & & \\
$\quad$ Junior High School & 3 & 4.47 \\
$\quad$ Senior High School & 46 & 68.80 \\
$\quad$ Higher Education & 18 & 26.73 \\
Occupation & & \\
$\quad$ Government employees & 21 & 31.34 \\
$\quad$ Farmer & 15 & 22.40 \\
$\quad$ Entrepreneur & 3 & 4.47 \\
$\quad$ Housewife & 28 & 41.79 \\
Parity & & \\
$\quad$ Primipara & 45 & 67.2 \\
$\quad$ Multipara & 22 & 32.8 \\
\hline Total & 67 & 100.0 \\
\hline
\end{tabular}

Azizah Midwife Clinic was 24 people (52\%) and the Pakem Health Center area included the Pakem Health Center, Muhammadiyah PKU Hospital, Felisiana Clinic, and Fitri Nurul Clinic. Most of the midwives' age were between 20-29 years, with 25 people or $53.1 \%$ (Table 1). Most education was D3, which were as many as 24 people (51\%).

From the respondents' characteristics questionnaire (Table 2), it was found that there were women who married early, as many as 3 people $(4.47 \%)$ of 67 postpartum mothers. Most of the postpartum mothers are women of childbearing age in the age range of 21-35 years, which was as many as 50 people (74.60\%). The most education was high school with as many as 46 people (68.8\%). The most common work was as housewives with 28 mothers (41.79\%). Parity was more prevalent with 45 primigravids (67.1\%).

\subsection{Level of knowledge of midwives}

After the training, a measurement of knowledge about social support, early detection and prevention of blues depression was done for midwives in the Cangkringan Health Center and Pakem Health Center. After being given training with lectures, discussions, simulations, and group presentations, there were changes in the average value of knowledge about prevention and early detection of blues depression from $43.45 \%$ before the training to $85.20 \%$ after the training (Table 3). Additionally, the knowledge of blues depression detection changed from $57.56 \%$ before the training to $91.27 \%$ after the training.

\subsection{Midwife skill level}

After the training, skills were measured in the early detection and management of blues depression among midwives in the Cangkringan Puskesmas and Pakem Puskesmas areas. There were changes in the average value of knowledge about prevention and early detection of blues depression from 36.45 before the training to 80.85 after the training, with an increase of 44.40 (Table 3).

\subsection{Tendency to blues depression in postpartum women}

The tendency of blues depression in postpartum women in the Cangkringan Community Health Center and Pakem Health Center Area changed after the training of midwives. The tendency of blues depressions in postpartum women in the Cangkringan Puskesmas and Pakem Puskesmas areas decreased by $57 \%$ to $24 \%$, or decreased by 16 people (33.00\%) (Table 4). Mothers who had no tendency of blues depression increased from the previous 29 people to 41 people with an increase of 12 people (17.30\%). 
Table 3. Distribution of midwifery' knowledge and skills items mean of scores regarding blues depression intervention dan early detection of blues depression.

\begin{tabular}{llll}
\hline Variable & Pretest & Posttest & Changes \\
\hline Knowledge of blues depression intervention & 43.45 & 85.20 & +41.75 \\
Knowledge of blues depression early detection & 57.56 & 91.27 & +33.71 \\
Social support skill & 36,45 & 80,85 & $+44,40$ \\
Early detection skill & 51,30 & 90,20 & $+30,90$ \\
\hline
\end{tabular}

Table 4. Score changes in the tendency of blues depression in postpartum mother

\begin{tabular}{lllllll}
\hline \multirow{2}{*}{ Variable } & Pretest & \multicolumn{3}{c}{ Posttest } & \multicolumn{2}{c}{ Changes } \\
\cline { 2 - 7 } & $\mathbf{F}$ & \% & F & \% & F & \% \\
\hline No tendency of blues depression & 29 & 43 & 41 & 60,70 & +12 & +17.30 \\
Blues Depression & 38 & 57 & 16 & 24.00 & -16 & -33.00 \\
\hline
\end{tabular}

\section{Discussion}

Increased knowledge of midwives will have an impact on preventing blues depression disorders in pregnant women in Puskesmas in Pakem and Cangkringan. This result is supported by the statement of several midwives that with training they can understand the true support of appreciation in the form of giving praise to postpartum mothers. Midwives can understand true and complete instrumental social support, understand information support with advice on how to provide baby care, enjoyable food to prevent blues depression, and better understand social companionship support and religious support. Before the training was held, midwives did not know about complete religious support. Usually midwives only advised mothers to accept life (dhikr), but did not pray to reduce their pain and suffering. After the training, the midwife learned that there was a need for religious support from the midwife by reciting prayers to reduce pain with gentle contact by stroking her stomach.

After training, midwives can provide empathy with social support and appreciation support as well as giving praise to the women who will give birth. Social support helps mothers develop and apply their personal maternal abilities and adapt better in difficult situations in order to reduce stress. ${ }^{6}$

Midwives can provide instrumental support in the form of touches of affection by stroking the mother's waist, shoulders, and forehead. In addition, midwives can provide religious support by giving prayers to reduce suffering, supportive advice by providing information related to how to breastfeed properly in order to increase the attachment between the mother and her baby and how to add food and drinks that increase good, healthy feelings to prevent blues depression.

Midwives who assist in childbirth in the Cangkringan Health Center and Pakem Health Center can provide social companionship support by diverting the mother's pain by sharing fun stories with sweet memories that are uplifting. After the training, there were changes in the knowledge about the early detection of blues depression using EPDS from the initial score of 51.30 to 90.20 , with an increase of 30.90. Increased knowledge and skills of midwives in providing social support for the prevention of blues depression and early detection will have an impact on preventing the occurrence of blues depression disorders in postpartum women in Puskesmas in Pakem and Cangkringan.

Midwives can provide prevention and treatment of blues depression through preparation of food intake that contains sufficient iron and drinks that can increase the good, healthy feelings in postpartum mothers so as to prevent the occurrence of blues depression. In addition, providing care during the time of pregnancy until the delivery process includes attentiveness, emotional support, appreciation (support awards), touch of affection, touch to sooth delivery (instrumental support), providing advice for strength, and boosts for endurance of the mother 
and baby (information support). The midwives can also provide prayers to reduce pain and facilitate labor (spiritual support). By inviting mothers to talk about something fun (social companionship support) they can provide prayers to reduce pain, facilitate childbirth, shift attention with funny stories, and share happy times for patients to divert pain, anxiety, in the face of childbirth.

The results of midwives' social support training in the Cangkringan Puskesmas and Pakem Puskesmas areas in the form of emotional support, rewards, instrumental advice, helpful information, social companionship and religious support were found to reduce the degree of blues depression in postpartum women. Providing emotional social support from midwives was done in the form of giving attention with affection. Social support rewards were done by giving compliments on the strengths and successes of mothers in undergoing labor. Instrumental support was done by giving a gentle touch on the belly, and caresses for postpartum mothers. Information support was done by providing advice on baby umbilical cord care, perineal care (birth canal), and eating foods that make the mothers feel healthy and happy, how to breastfeed properly and demonstrating ways to improve the attachment of the mother and her baby.

Social support provided by midwives will increase the mothers' feelings of calmness and satisfaction, increase dopamine, which will increase feelings of happiness, and security, and increase the hormonal endorphins which will ultimately reduce stress and depression. ${ }^{8}$ Providing social support from midwives during childbirth, time to go home and initial time of baby care was done in the form of giving attention, affection, prayer, appreciation, advice and preparing husbands to provide support during childbirth which can make postpartum women become more confident, increase self-esteem and calmness. ${ }^{8}$ These supports will reduce stress hormones, and cortisol levels which in turn will reduce the degree of blues depression.

The husband's social support that was given by midwives in providing social support during the postpartum period for postpartum mothers took the form of instrumental support, which included among others ways: helping to care for the baby, massaging if the mother is tired, holding the baby, changing diapers at night and helping to pray to reduce pain if the mother experiences pain in the breast and uterus. Emotional support involves paying attention to the mother's needs, calming the mother when she is restless, she does not feel happy, feeling sad, or angry, and comforting her when she feels insecure and anxious. ${ }^{9,10}$

Research has showed that social support from midwives and husbands will reduce the potential for a mother to have severe blues depression. 1,7,11,12,7 Women who feel cared for, valued, and loved, will increase their confidence and self-esteem so that they can reduce blues depression. Satisfaction from social support that is obtained by postpartum women will increase their comfort, help them relax, reduce fear, anxiety, and stress which in turn can reduce blues depression. ${ }^{13}$

Biologically, the satisfaction of social support is due to the chemical bonding between dopamine and dopamine receptors in the nucleus accumbens which can reduce cortisol secretion and stimulate oxytocin release. ${ }^{14}$ Decreasing cortisol and increasing oxytocin reduce sympathetic nerve activity. This biological process will create a sense of comfort, relaxation, reduce the state of stress, fear and anxiety, thereby reducing the physiological effects of postpartum stress which in turn will reduce blues depression. ${ }^{15,16}$

\section{Conclusion}

Midwife training can improve midwife knowledge and skills in early detection and prevention of blues depression in postpartum mothers in the Cangkringan Puskesmas and Pakem Puskesmas, and as a result, there was a decrease in the tendency for blues depression in postpartum mothers in the Cangkringan Puskesmas and Pakem Puskesmas. The outcomes obtained from this community service project are expected to be part of the permanent program of the Puskesmas or maternity clinics in the Cangkringan Puskesmas and Pakem Puskesmas areas. Midwives should be more skilled in early detection of blues depression and skilled in providing social support in post-natal services in order to prevent serious episodes of postpartum depression. 


\section{Acknowledgements}

1. To the Directorate of Research and Community Service, the Directorate General of Research Strengthening and Development of the Ministry of Research, Technology and Higher Education who has provided trust, funds, and facilities for the implementation of these community service activities.

2. To drg. Ika Dewi Ana., Ph.D. as Vice Chancellor for Research and Community Service at Universitas Gadjah Mada and all staff who have given permission and facilitated community service activities.

3. To the Head of the Sleman District Health Office and all staff who have given permission to conduct community service activities in the Cangkringan Community Health Center and Pakem Community Health Center.

4. To Sugeng Budi Setio Utomo., S.T as the Head of the Cangkringan Community Health Center along with all of his staff who have given permission and provided facilities to conduct this community partnership program activity.

5. To the Head of Puskesmas Pakem along with all his staff who have given permission and provided facilities to conduct the activities of this community partnership program.

6. To Midwives and Medical Personnel at the maternity clinic in the Cangkringan Community Health Center area including PKU Muhammadiyah Cangkringan, BPM Azizah, BPS Kisti Arum, Pustu Kepuharjo, and Pustu Wukirsari.

7. Midwives and Medical Personnel at the maternity clinic in the Pakem Puskesmas area including PKU Muhammadiyah Pakem, Felisiana Maternity Clinic, and Fitri Nurul Maternity Clinic.

8. To the postpartum mothers who have played an important role in the implementation of this community partnership program.

\section{Conflict of interest}

The authors declare that there are no conflicts of interest.

\section{References}

1. Sumarni, Silas HI, Elsi DH, dan Wenny AN. Identifikasi Blues Depression dan Faktor-faktor Psikososial yang mempengaruhi serta Upaya Penanganannya pada Wanita Postpartum di Huntap Kecamatan Cangkringan Kabupaten Sleman. Yogyakarta [Laporan Penelitian Dana Masyarakat]. Fakultas Kedokteran, Kesehatan Masyarakat, dan Keperawatan, Universitas Gadjah Mada; 2013.

2. Hadianto, Sumarni. Faktor-faktor sosial budaya yang mempengaruhi blues depression serta upaya penanganganannya pada wanita postpartum pasca gempa di Puskesmas Jetis Bantul: Laporan Penelitian Sekolah Vokasi Universitas Gadjah Mada; 2014.

3. Pitaloka RRA. Religi dan Spiritualitas Sebagai Coping Stres dalam Penanganan Psikologis Korban Tsunami [tesis]: Jakarta; Universitas Bina Nusantara; 2015.

4. Puskesmas Pakem. Buku Profil Puskesmas Pakem. 2010-2015. Sleman, Yogyakarta.

5. Hardianto, Sumarni. Pelatihan Suami dan Bidan dalam Penanggulangan Postpartum Blues di Desa Purwobinangun Pakem Sleman. Yogyakarta: Universitas Gadjah Mada, LPPM; 2015. Laporan Pengabdian Masyarakat LPPM UGM.

6. Saeieh SE, Rahimzadeh $M$, Yazdkhasti $M$, Torkashvand S. Perceived social support and maternal competence in primipara women during pregnancy and after childbirth. Int I Community Based Nurs Midwifery. 2017; 5(4):408-416.

7. Stahl SM. Stahl's Essential Psychopharmalogy: Neuroscientific Basic and Practical Applicatios, $6^{\text {th }}$ ed. New York: Cambridge University Press; 2017.

8. National Partnership for Women \& Families. Continuous support for women during childbirth: 2017 Cochrane Review update key takeaways. $J$ Perinat Educ. 2018;27(4):193-197.

9. Wilson $\mathrm{CL}$, Simpson JA. Childbirth pain, attachment orientations, and romantic partner support during labor and delivery. Pers Relatsh. 2016;23(4):622-644.

10. Corrigan CP, Kwasky AN, Groh CJ. Social support, postpartum depression, and professional assistance: a survey of mothers in the midwestern United States. J Perinat Educ. 2015;24(1):48-60. 
11. Zakiah. Gambaran Dukungan Sosial Keluarga Terdekat terhadap Ibu Postpartum Primipara di wilayah Puskesmas Mergangsan [skripsi]: Yogyakarta; Fakultas Kedokteran Universitas Gadjah Mada. 2007.

12. Mardiah S. Hubungan Usia Ibu dengan Gejala Blues depression di wilayah Kota Tasikmalaya [tesis]. Yogyakarta; Program Pascasarjana Universitas Gajah Mada. 2015.

13. Hunter J. An intervention to improve the comfort and satisfaction of nurses in the telephone triage of child maltreatment calls. Pediatr Nurs. 2015;41(6):296-300.
14. Sippel LM, Allington CE, Pietrzak RH, HarpazRotem I, Mayes LC, Olff M. Oxytocin and stressrelated disorders: neurobiological mechanisms and treatment opportunities. Chronic Stress (Thousand Oaks). 2017;1.

15. Miyazaki T, Takase K, Nakajima W, et al. Disrupted cortical function underlies behavior dysfunction due to social isolation. J Clin Invest. 2014;124(6):2807.

16. Davidson CC, Neale JM, Kring AM. Psikologi Abnormal Edisi ke-9. Jakarta: PT Raja Grafindo Persada; 2018. 